\title{
Daily behaviour of Hungarian Grey Cattle under range grazing conditions
}

\author{
András Halász - Géza Nagy \\ University of Debrecen Centre for Agricultural and Applied Economic Sciences, \\ Faculty of Applied Economics and Rural Development, Institute of Rural Development and Functional Management, Debrecen \\ halasza@agr.unideb.hu
}

\section{SUMMARY}

\begin{abstract}
Cattle behaviour on rangeland depends on external factors, such as grass allowance and quality, temperature, net solar radiation, distance from water-source, wind speed and direction, air pressure changes and the applied breeding technology. Our research is based on previous empirical observations and modern methods to analyze the behaviour of the Hungarian Grey Cattle. Today it is crucial to use cost-effective solutions in modern beef cattle farming therefore we introduce a cost-efficient method to study and follow cattle herds. We are studying relation between traveled daily distance and air pressure. The various weather fronts influence behavioural characteristics and traveled daily distance. According to our hypothesis, the pressure-change and the wind direction has significant effect on cattle activity on pasture. As the different air masses alter the barometric conditions and unbalance the neuroendocrine system, indirectly cause relaxed or agitated behaviour
\end{abstract}

Keywords: cattle behaviour, tracking, weather, GPS, ethology

\section{ÖSSZEFOGLALÁS}

A szarvasmarha viselkedése a legelön, függ az olyan külső tényezöktöl, mint a fükínálat és minöség, hömérséklet, besugárzás, itatótól való távolság, szél-sebesség és -irány, légnyomás-változás és az alkalmazott tartástechnológia. Kutatásunk a korábbi empirikus megfigyeléseket és modern módszereket egyaránt figyelembe veszi, hogy kiértékeljük a magyar szürke marhák viselkedését. Napjainkban elengedhetetlenek a költséghatékony megoldások a húsmarha tartásban, ezért bemutatunk egy gazdaságos módszert a gulyák megfigyelésére és nyomon követésére. A légnyomás és a naponta megtett távolság kapcsolatát vizsgáljuk. Az idöjárási frontok hatással vannak a viselkedési jellemzökre és a megtett napi útvonalra. Hipotézisünk szerint a légnyomás változás és a szélirány jelentösen befolyásolja a húsmarha aktivitását a legelön. Mivel a különbözö légtömegek befolyásolják a légnyomásviszonyokat és felborítják a neuroendokrin rendszer egyensúlyát, ezzel közvetve nyugodt vagy izgatott viselkedést idéznek elö.

Kulcsszavak: szarvasmarha viselkedés, nyomon követés, időjárás, GPS, etológia

\section{INTRODUCTION}

The modern ethology were established by Conrad Lorenz, an Austrian professor of zoology in the 1950's. According to his concept the animal behaviour has to be approached in an evolutional framework. The basic interest of organisms is to inherit their genetical pattern and spread it among the next generations. In order to do so, they have to reproduce and have to make as many offspring as possible. Any kind of behavioural pattern feeding, communication, protection against predators, social interactions has to support this effort of the animal. Lorenz pointed out, that the animal behaviour may be divided in trait groups. These traits can occur voluntarily or involuntarily (Taylor and Field, 1998). The professor has proved animal behaviour may be described in detail and the result may be evaluated statistically. Since the very beginning aspects of ethological research have been broaden, and the scientific value of them increased.

Széky (1979) in his book titled "Ethology", summarises the patterns of animal behaviour, suggested to organize them in groups according to functions in the ethogram (the form of written record used for observations in animal behaviour research). He has divided behaviour patterns into: navigation, body care, metabolism, attack and defence, building activity, territorial behaviour, reproduction and social interactions.
Czakó et al. (1985) in his book on animal behaviour describes in details the general animal behaviour patterns, which should be included in an ethogram. He classified: movements (swimming, flying, walking), comfort activities (bathing, feather care, scratching), navigation (solar, chemical scents), metabolism (food intake, respiration, urination and defecation), defensive behaviour (territorial, defence, attack), reproductive behaviour (partner selection, mating-dance, mating, offspring care), social interactions (dominant and recessive traits) building activities (nest, digging), communications (voice, mimics, body pose), playing (within species among species, practicing adult behaviour).

Ungar et al. (2005) classified animal behaviour patterns of grazing animals into 5 groups: grazing, resting, laying, standing and moving.

With the overall technical developments, research methodologies have been improved as well. At the very beginning the visual observation was common, later on special equipments for automatic measurement were developed (Hodgson, 1982), in recent times IT and satellite assistance is available for targeted field research [Garmin 76 CSX handheld GPS receiver (Net 1), Bluetooth GT-750 F GPS data logger (Net 2), GS-Traq TR-203 Personal tracker (Net 3)].

Since the old historical times there have been empiric observations about the behaviour of grazing cattle. 
Herdsmen looking after animals from day to day were active contributors in the development of this practical knowledge, called "shepherd-science".

Both in the international and the Hungarian publications (Horn, 1955; Bodó, 1968; Czakó, 1974; Haraszti, 1977) animal behaviour research on pasture was primarily focused on dairy cattle. The dairy industry is more intensive farming system for cattle, and the consequences from the ethological research could be used for the improvement of the economic efficiency of the production. The primer grazing breed in extensive Hungarian rangeland farming is the Grey Cattle. She is member of the ancient Podolic cattle group, which has semi-wild nature, and therefore prefers to graze on large rangeland areas out of any human influence.

We attempt to answer the following questions:

- How weather fronts influence animal behaviour?

- Which behavioural pattern influenced by weather conditions?

- Prove the connection between air pressure changes and daily walked distance.

\section{MATERIALS AND METHODES}

The study area is 1191 ha rangeland. There are two major parts: the North (688 ha) and South (503 ha). The Hortobagy River and two local shadoofs (dug well) are the only water sources. The $10(n=10)$ observed individuals are marked with coloured calf rope for visual identification. The different coloured ropes have tied around the neck. The ropes are sturdy enough to resist rough/range conditions and the plastic colour cover on the ropes can resist against the ultra-violet radiation of the sun. The colour ropes can be recognized from long distance and the animals will not be bothered during behavioural observations. The animals keep 50-100 m flight-zone therefore high vis-markers are essential.

Only the gallery forest and the river bank provide wind shelter. The herd does not receive supplementary feed during the grazing season and in the winter housing hay and salt fed only. The cattle every time returns to the herd-hut - shadoof and elevated, dry calving-mount throughout the grazing-season. We apply the Czakó et al. (1985) terminology to describe the animal behaviour and organize the behavioural traits in 3 main groups. The feed intake actions (grazing, rumination, drinking), sexual and calf care actions (copulation, nursing) and social actions (fight, play, moving). Two type of GPS receivers have been used (Snewi Trekbox, Bluetooth, GT-750 GPS data logger) to describe the animals spatial position and calculate the speed, the daily travel distance and the time spent with standing. The loggers recorded for 5 days of animal daily route. The positional data have been transformed to digital mapping. Trotter et al. (2010) has made significant progress in precision farming and satellite tracking for cattle. His work is a bright bacon to our study regarding digital mapping and developing tools. The daily weather data, like wind speed, temperature, air pressure and the medical weather-front reports help us to build the daily weather model which is compared with the daily routes.

Animal behaviour has been observed periodically, in every 20 minutes, and the duration of recording approximately 5 second each. The most typical behaviour pattern has logged. Finding labelled animals, we used a binocular. It is necessary to avoid bothering the animals. The problem of the "flight zone" (distance kept from strangers) managed by using a land rover/bantam car (Malechek and Smith, 1976). The typical behavioural patterns (grazing, fighting, calf care) have been recorded with digital video camera. Meteorological data collected from the national meteo survey data base and we also made local measurements (air pressure, temperature). The statistical analysis created by SPSS software pack. During the field work, we continue to refine the observation methods. The virtual fencing (Bishop-Hurley et al., 2007), and the GPS-based, alarm systems (Tell Ltd. and own development) are also promising perspectives.

\section{RESULTS}

The front-free or cold front weather systems cause high air pressure $(\mathrm{P} \geq 1005 \mathrm{hPa})$ which results calmer behaviour. The relaxed cattle spends more time feeding. Seeking for fresh, nutritious grass is a natural herbivore behaviour (Gere, 1977) therefore a non stressed herd's pasture-activity is $80 \%$ feeding. Results show that warm-weather front - low air pressure $(\mathrm{P} \leq 1005 \mathrm{hPa})-$ cause more stress because the changing (dropping) air pressure effect on the parasimpatic nervous system (Kovács, 2010) and often combined with high temperature and humidity. The stressed animals gather, spend more time in shade at nearby water-source (river-bank). According to the preliminary analysis there is a connection between stable weather system and the increased feeding activity (table 1).

The research area is almost completely flat rangeland where the prevailing north-eastern wind is not broken by hills or dense forest. It is an old verdict that every furry animal in open grassland try to avoid to get wet simply because the wet fur does not let much isolating air among the hairs. Our observations have confirmed that grazing cattle in windy-cold-wet weather is always looking for wind-shelter and walking the same direction as the wind blows. Reeds, irrigation-canals and riverbanks force the wind higher altitude, resulting lower wind-speed at ground level. Only in summer time the herd is looking for gentle breeze to regulate body temperature and get rid off hundreds of giant horse-fly. As a summary we can say that the herd is moving parallel with wind direction. Summer time toward the wind, winter time away from wind. See picture 1. 
Distribution of behavioural traits during different weather system from 2010 to 2011

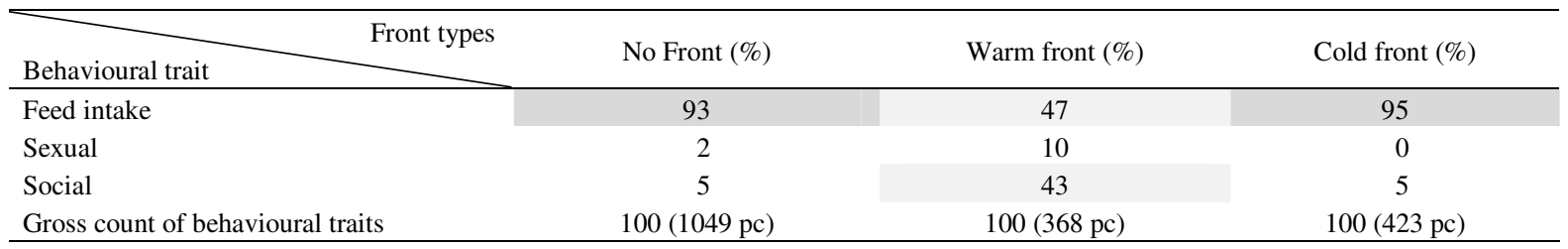

Source: own calculation

Note: $\mathrm{n}=10$ - marked cattle

Picture 1: Cattle movement in North-eastern wind at the research area

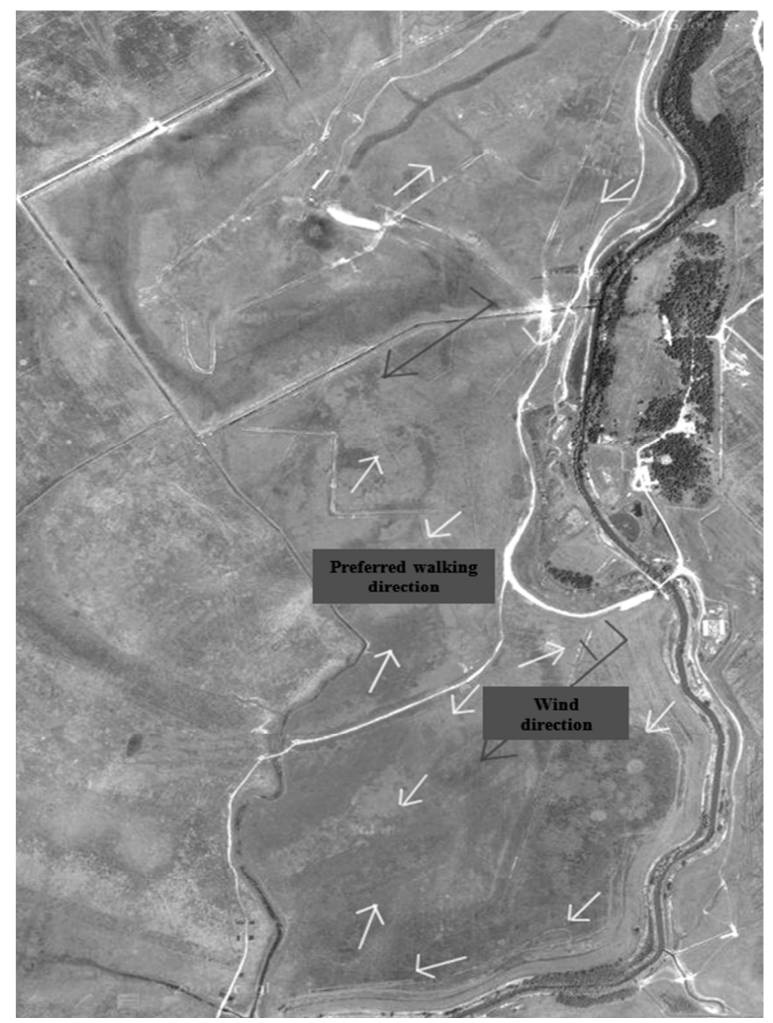

Source: own work

\section{CONCLUSIONS}

The Hungarian Grey Cattle at the rangelands of Hortobágy is sensitive of the weather changes and the wind direction. The preliminary results show that the livestock movement patterns and daily traveled distance are in close connection with wind direction and weather fronts. The research has developed methods of measurement (animal tracking, grazing preferences) for the daily farming practice.

Hungarian Grey Podolic Cattle, under traditional grazing system, has totally adapted to unregulated semi-wild conditions. New results on behaviour of the Hungarian Grey Cattle will contribute to increase the reputation/fame of this great and unique cattle breed.

\section{ACKNOWLEDGEMENT}

The work/publication is supported by the TÁMOP4.2.2/B-10/1-2010-0024 project. The project is cofinanced by the European Union and the European Social Fund.
Bishop-Hurley, G. J-Swain, D. L.-Anderson D. M.-Sikka, P.-Crossman, C.-Corke, P. (2007): Virtual fencing applications: Implementing and testing an automated cattle control system. Computers and Electronics in Agriculture. 56: 14-22.

Bodó I. (1968): A magyar szürke marha küllemének és teljesítményének megítélése. Gödöllő. Doktori értekezés.

Czakó J. (1974): Gazdasági állatok viselkedése. Mezőgazdasági Kiadó. Budapest.

Czakó J.-Keszthelyi T.-Sántha T. (1985): Etológia Kislexikon. Natura Kiadó. Budapest.

Gere T. (1977): Néhány tartástechnológiai tényező hatása a szarvasmarha viselkedésére. Különlenyomat az Agrártudományi Egyetem Gödöllő 1977. évi közleményeiből.

Haraszti E. (1977): Az állat és a legelő. 2. kiadás. Mezőgazdasági Kiadó. Budapest.
Hodgson, J. (1982): Ingestive bahaviour. [In: Leaver, J. D. (ed.) Herbage intake handbook.] Chapter 6.

Horn A. (1955): Általános állattenyésztés. Mezőgazdasági Kiadó. Budapest. 160-180., 583-609.

Kovács A. (2010): Agrometeorológiai és klimatológiai alapismeretek. Zoometeorológia. 263-290.

Malechek, J. C.-Smith, B. M. (1976): Behavior of Range Cows in Response to Winter Weather. Journal of Range Management. 29: 9-12.

Net1: Garmin 76 CSX kézi GPS-vevő (https://buy.garmin.com/ shop/shop.do?pID=351\&ra=true)

Net2: Bluetooh GT-750 F GPS data logger (http://www.fantechelectron.com/enu/product/view/gt-750fl-lite-usb-gpsreceiver.htm) 
Net3: GS-Traq TR-203 Personal tracker (http://www.globalsat. com.tw/productspage.php?menu $=2 \& g s \_$en_product_id $=3 \& g s$ _ en_product_cnt_id=23)

Széky P. (1979): Etológia, Natura Kiadó. Budapest. 26.

Taylor, R. E.-Field, T. G. (1998): Scientific Farm Animal Production. An Introduction to Animal Science. $6^{\text {th }}$ Edition. 702. New Jersey. Prentice-Hall Inc. [Provides an overview of animal industries with detailed information regarding animal products and all aspects of health, breeding, and care.]
Trotter, M.-Lamb, D. W.-Hinch, G. N.-Guppy, C. N. (2010): GNSS Tracking of livestock: Towards variable fertilizer strategies for the grazing industry. Precision Agriculture Research Group Conference. University of New England. Armidale. Australia. Ungar, E.-Henkin, Z.-Gutman, M.-Dolev, A.-Genizi, A.-Ganskopp, D. (2005): Inference of Animal Activity From GPS Collar Data on Free-Ranging Cattle. Rangeland Ecology Management. 58: 256-266. 